\title{
Biography of a snake charmer in Saidpur, Bangladesh
}

\section{Summary}

Though Saidpur Upazila under Nilphamari district is very small but here pigeonry, goat rearing, herbal treatments, circus team, monkey charmer, horse race and snake charmers are available. Snake charmers are not living well in this modern era. Their kids are not safe at home for snake rearing. In Savar, Dhaka there is a snake market where some tribal people buy it as food. People who are engaged with snake catching and snake-based superstitions go to that market. They support medical science and are waiting to get a good job. Who take snakes as food they say its meat is very hot. Depending on body size its price varies from 1000 to 2000 taka of a poisonous snake. People of the circus team, zoo committee and intersex people collects snakes from the snake charmer. Tradition of snake charming in Bangladesh is very ancient. Once upon a time most of the villagers liked it. Some peoples were considered as bede or tribal people who caught snakes from the jungle. Though Bangladesh is a small country but its 80 species of snakes are remarkable. Within these only cobras, kraits and sea snakes are poisonous and most of the cobras are bicellate type. Common vine snakes, tree snake and rat snakes are very common and nonpoisonous snakes of Bangladesh. After catching a snake, the charmer cuts the poison sac or rubs both fangs of the snakes. As poison of the snakes are digestive juice so that those snakes can suffer digestive ailments and ultimately die. The temperature of Rangpur division of Bangladesh is $350-370 \mathrm{~F}$ which is suitable for snakes' survival. There were $30.77 \%$ poisonous and $69.23 \%$ non poisonous snakes' in Bangladesh in three families. ${ }^{1}$ In Bangladesh out of 82 species 28 are venomous and 12 are sea snakes. ${ }^{2}$ Estimates indicate $>5$ million bites annually by venomous snakes worldwide where $>12500$ deaths..${ }^{3,4}$ Some research work have completed on snakes taxonomy, status, distribution and epidemiology of snake bite. $^{5-7}$ India has the highest number of snake bites in the world with 35000-50000 annually according to World Health Organization. ${ }^{8,9}$ In Bangladesh this is 4.3per 100000 an annual incidence and case fatality is $20 \% .^{10}$
Volume 3 Issue 4 - 2018

\author{
Ashraful Kabir \\ Department of Biology, Saidpur Cantonment Public College, \\ Bangladesh
}

Correspondence: Department of Biology, Saidpur Cantonment Public College, Nilphamari, Bangladesh, Email ashraful.mission@gmail.com

Received: August 01, 2018 | Published: September 04, 2018

\section{Species of snakes and their management}

\section{Snake species}

There were four snakes where two spectacled cobra (Naja kaothia) (one adult and one juvenile). One was monocled ( $N$. naja) and another tree snake (Ptyas mucosus). Rat snake was measured 7 feet long, female monocled was 5 feet and two spectacled cobras both were adult female about 6 feet and juvenile 3 feet (Figure 1). Snake charmer of Saidpur Md. Abul Kashem he had 30snakes few days ago including poisonous and nonpoisonous (Figures 1-3).
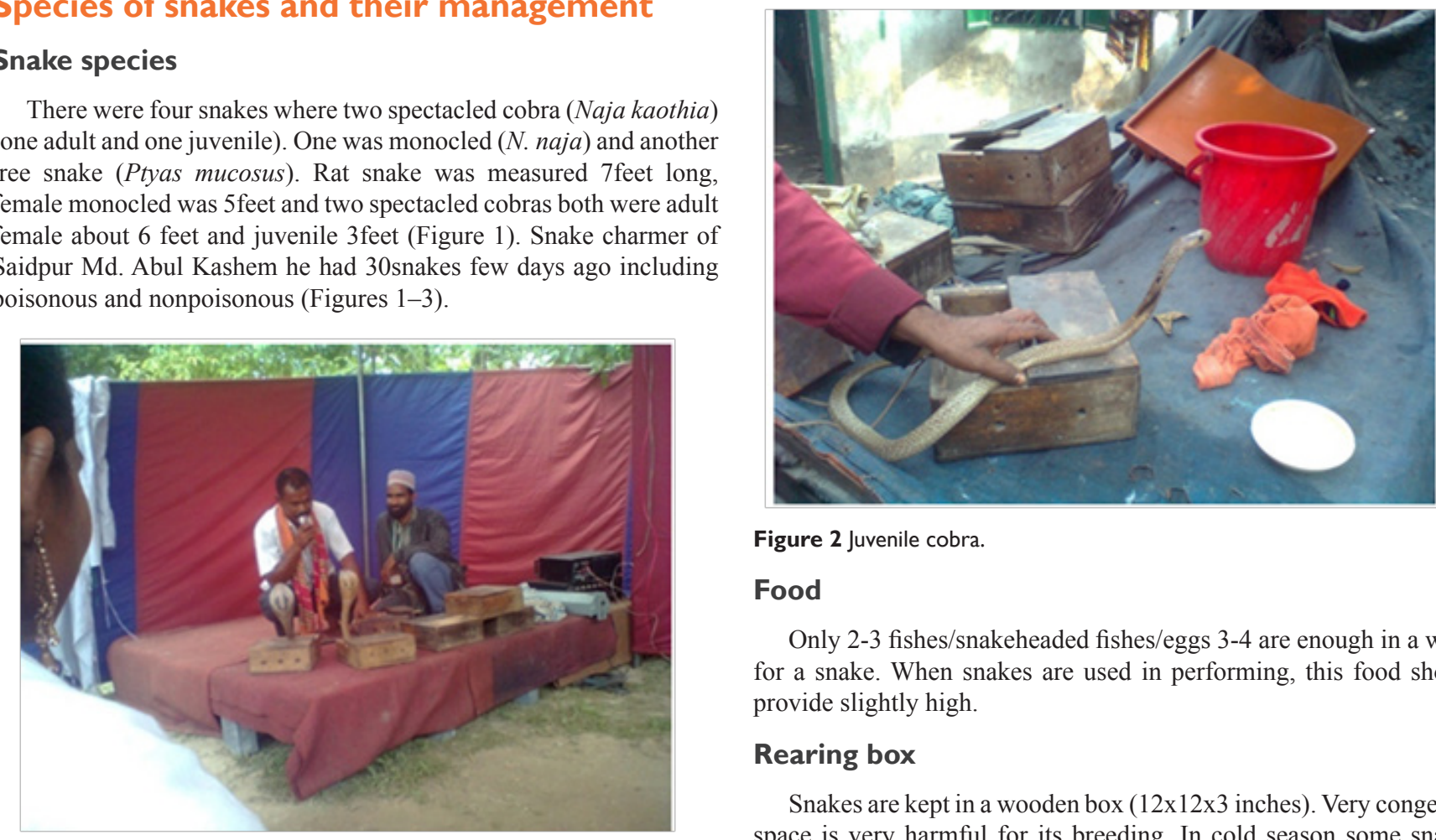

Figure 2 Juvenile cobra.

\section{Food}

Only 2-3 fishes/snakeheaded fishes/eggs 3-4 are enough in a week for a snake. When snakes are used in performing, this food should provide slightly high.

\section{Rearing box}

Snakes are kept in a wooden box $(12 \times 12 \times 3$ inches). Very congested space is very harmful for its breeding. In cold season some snakes die. Each snake needs two hours sunlight everyday (Figure 1). Body

Figure I Abul Kashem with cobras. 
temperature of a diseased snake is high and it shows very anger and enlarges its eye. This situation is very dangerous while performing.

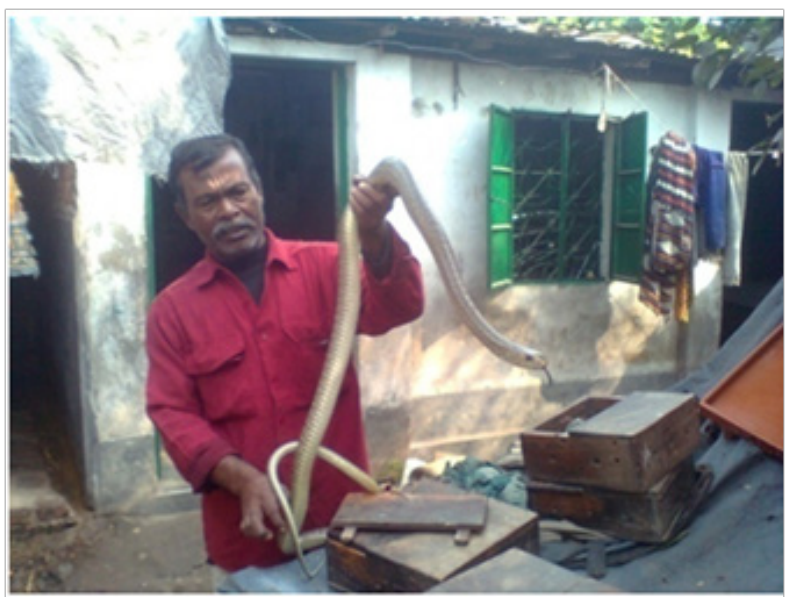

Figure 3 Charmer with rat snake.

\section{Catching technique}

Snake charmer does not use any kits for snake catching. They catch snake by open hand. They just try to concentrate snakes eye to the charmers' hand one hand and by using another hand they hold the head/neck of that snake. If that snake sudden moves back it may bites. Snake charmers know about snake catching sticks like L stick, T stick, Y stick and grab stick. Snake charmer does not catch that snake which has eggs in their ovary. Snake charmer, Md. Abul Kashem had a trained mongoose which played with snakes. If pet mongoose is welltrained not happen any harms for snakes otherwise for mongoose's bites snakes may die

\section{Discussion}

There are many superstitions about snakes in the country. ${ }^{11}$ The jewel of the snakes' head, snakes dancing by whistle in movies and milk sucking of rat snake from cow is more famous story of Bangladesh but all are scientifically false. Pet of odd animals like snake is not suitable for hobby. ${ }^{12}$ Most people fear to see snakes. This is odd pet so that do not rear snake at home and playing with them. ${ }^{12}$

\section{Conclusion}

Snake charmer wants suitable job except the snake charming. In this modern world, their old traditional treatment for snake biting is not scientific. Most of the snake rearers die by snake bite. Snake charmer Md. Abul Kashem in Saidpur is passing very risky days at his home with their kids. In Bangladesh there are maximum one lac bedes or snake charmers. Some NGOs are playing major role in this country for increasing awareness for snake biting. Antivenom vaccine is not available in Bangladesh. In village, if any snake bites, traditional treatment is life-threatened to the victim. Snakes can be used in biological control and venom for making anticancerous drugs. We need to establish a modern snake lab where venom will be collected for human welfare. ${ }^{13}$

\section{Recommendations and implementations}

There are lots of superstitions about snakes in rural or urban areas of Bangladesh. Snakes' meat is used for some diseases. ${ }^{11}$ Most cobra and krait bites in Bangladesh were recorded between May and October and highest in June. Poor medical facilities in rural areas, high cost of treatment and inadequate supply of antivenom vaccine are our major problems..$^{14,15}$ The time of biting by cobra happens in late afternoon..$^{15,16}$ All snake collectors and exporters must be licensed under the 'Directorate General of Forest Protection and Nature'. Most people know that snakes are harmful and when it comes out they killed instantly. ${ }^{17}$

\section{Acknowledgements}

None.

\section{Conflict of interest}

Author declares that there is no conflict of interest.

\section{References}

1. Kabir MA. Snakes' availability and its biting record in Rangpur Carmichael College, Bangladesh. J Biol Chem Research. 2013;30(1):319-328.

2. Faiz MA, Hossain M, Amin R. National guideline of management of snake bite. $2^{\text {nd }}$ ed. Dhaka: DGHS; 2008.

3. Fernando B. Kraits and wolfsnakes-the karawalas. Loris. 1997;14:157.

4. Paul S, Auerbach, Robert L. Disorders Caused by Reptile Bites and Marine Animal Exposure. In Fauci AS, Braunwald E, Kasper DL editors. Harrison's Principles of Internal Medicine. $17^{\text {th }}$ edn. New York: The McGraw- Hill Companies; 2008. p. 2741-2748.

5. Ahsan MF 1998. Country report for Bangladesh-Herpetofauna of Bangladesh: present status, distribution and conservation. In: A. de Silva editors. Biology and conservation of the amphibians, reptiles and their habitats in South Asia (Proceedings of the International Conference on the Biology and Conservation of Amphibians and Reptiles of South Asia, Sri Lanka; 1996. p. 1-5.

6. Khan MAR. Checklist of the herpetofauna of Bangladesh. Cobra. 2004;57:1-29.

7. Sarker NJ, Sarker SU. Observation of some snakes of Bangladesh. Tiger paper. 1993;20(3):17-21.

8. Kasturiratne A, Wickremasinghe AR, de Silva N, et al. The global burden of snakebite: a literature analysis and modelling based on regional estimates of envenoming and deaths. PLoS Med. 2008;5(11):e218.

9. Warrell DA. WHO Guidelines for the clinical management of snake bites in the South East Asia Region. SE Asian J Trop Med Publ Health. 1999;30:1-83.

10. Sarker M, Sarker N, Patwary S. Epidemiological survey of snake bite incidences in Bangladesh. Dhaka University J Biol Sci. 1999;8:53-68.

11. Kabir MA. Superstitions and traditional uses of animal in Bangladesh. Standard Journal of Biological Sciences. 2014;1(1):5-8.

12. Kabir MA. Human cruelty and love to animals. Intl $J$ of Res Studies in Zoology. 2016;2(2):1-8.

13. Rabies and Envenomings, A neglected public health issue. Geneva: WHO; 2007.

14. Simpson ID. The "worldwide shortage" of antisnake venom: is the only right answer "produce more" or is it also "use it smarter?". Wilderness Environ Med. 2008;19(2):99-107.

15. Warrell DA. Clinical toxicology of Snake bites in Asia. In: White MA, editor. Handbook of clinical toxicology of animal venoms and poisons. CRC Press. 1995. p. 493-588.

16. Whitaker R, Captain A. Snakes of India, the field guide. Chengalpattu: Draco Book; 2004.

17. Azam MS, Alam SS, Shah MR. Country report of Bangladesh on CITES Asian Snake Trade Workshop. 2011;11-14. 